\title{
水源の水質污濁に対する水道事業体の取り組み* 大阪市水道局の例
}

\section{はじめに}

淀川は, 京阪神 1,000 万人の人々の水道水源となって いる。上中流域には大都市が連接し，その排水のほと んどが淀川に還元され，その下流で水道水源として利 用されるという, わが国では特異なくり返し利用型水 系といえる。

したがって，明治28年大阪市が淀川を水源として近 代水道を創設して以来, 浄水処理方式の選定には多く の水質調査と処理実験が実施されてきた。

大阪市水道 90 年の歴史をみると, 水道水の安全を確 保する方式を 3 つの時代に区分できる。創設当初から およそ30年間は, 砂濾過のみで安全を確保しえた時代, それに続く昭和のはじめから約 30 年間は, 砂濾過に加 えて塩素消毒をして安全を確保した時代である。すな わち，これまでの期間は微生物污染に主眼が招かれて いた。最近の約 30 年間は塩素を消毒剂としてのみでな く, 浄水処理薬剤としても利用し, 不連続点塩素処理 によって, 安全の確保に努力してきた。

そして現在, 琵琶湖で発生するカビ臭に対する市民

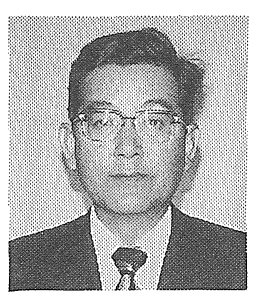

Toshiharu Yoshitake 昭和36年 北海道大学工学部卒業 同年 大阪市水道局柴島浄水場 58 年 同水質試験所調査主幹 61年 同水質試験所所長 技術士（水道部門）

〔趣 味〕ゴルフ 生花

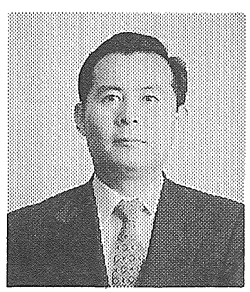

Masashi Kajino

昭和 33 年 大阪市水道局水質試験所 39 年 近幾大学卒業

55 年 大阪市水道局工務部水質試 験所主查 工学博士 技術士

〔趣 味〕テニス 卓球 旅行

* Counter Measures of Water Works against the Source Water Pollution, 昭和61年 5 月 27 日受理

\section{吉 竹 俊 治梶野 勝 司}

の不快感と不安感, トリハロメタンをはじめとする微 量物質に対する不安感から「扣いしい水」の要求が強 くなってきている。水道事業者は水源水質保全のあり 方と水道に沶ける高度処理のあり方等, 次の時代の水 道システムを模索しているところである。

本論は，不連続点塩素処理を採用して安全性を確保 した頃からの淀川水質の状況と, 現在大阪市が取り組 んでいる水道水の安全性確保に関する調査研究の概要 を紹介するものである。

\section{1. 淀川の水質污濁の状況と浄水処理}

\section{1 有機的污濁と浄水処理}

淀川は，沿川流域内の人口増によってその水質は污 濁化の傾向を辿ってきたが，昭和 20 年の終戦時には一 時的に水質は回復した。しかし，人々が都市にもどり 生産活動をはじめると共に, 污濁の傾向を示しはじめ た。戦後最初に浄水処理を困難にしたのは, 降雨後の 高濁度であった。これは荒廃した山河によるものであ り, 植林, ダム建設等の整備が進むにつれて解決され てきた。

昭和 30 年頃からの経済成長期には排水処理設備, 下 水道が未整備, 諸産業の成長, 都市への人口集中, 農 業の近代化に伴ららん尿の河川への排水等がみられ, 淀川の污濁はすさまじい勢いで進行した。

淀川の下流, 柴島取水点の BOD とアンモニア性窒 素の経年変化図（図 1) にこのことが良く示されてい る。

これらの污濁物質は河川水中の溶存酸素を消費し，

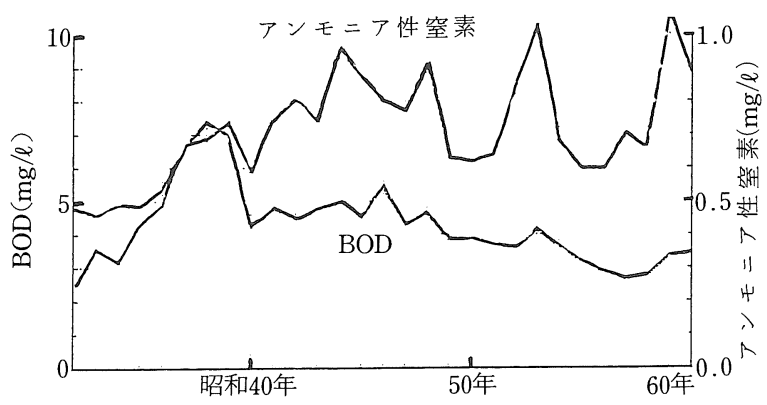

図 1 柴島浄水場原水水質の経年変化 


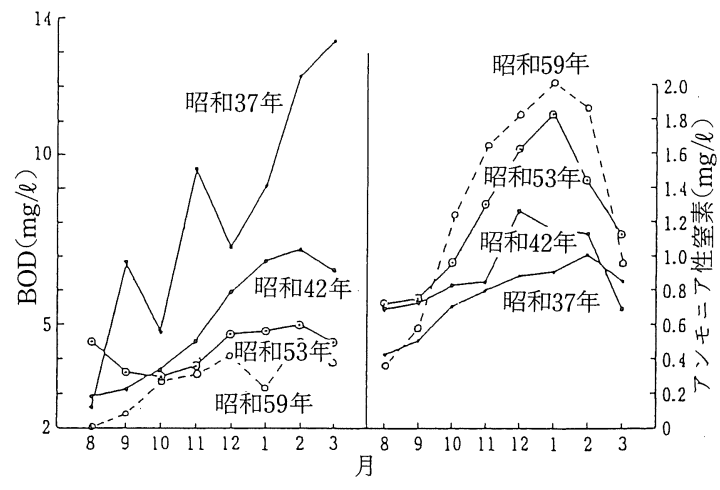

図 2 淀川柴島地点の渴水時における $\mathrm{BOD}$ とアンモニア 性窒素

河川を嫌気状態にする。このような所に降雨があると 污濁物質を一気に押し流し，堆積した底泥をもまき上 げ，広範囲に無酸素状態を作り出し，魚がへい死浮上 する現象が生ずる。昭和 33 年 6 月には淀川本流でこの ような現象がみられたのである。大阪市柴島浄水場で は，魚のへい死が無酸素状態によるものであり，毒物 によるものでないことを確認するまで, 取水を停止せ ざるを得なかった1)。のような有機的锧濁物質による 黒濁り現象は, 晴天が続いた後の降雨の度に経験する こととなった。

著しい污濁が進行していた昭和 37 年，淀川は渴水に 見舞われた。渴水時の淀川水質を比較すると図 2 のよ らである。淀川での流量減少が水質に大きく影響する のである2)。

当時大阪市は, 緩速濾過と急速濾過の 2 つの方式で 浄水処理をしていた。緩速濾過は水中の夾雑物の増加 により目詰まりが早く,その維持作業に困難をきわめ, すでに常時硫酸アルミニウムを使用していた。そして， 原水の BOD の増大, アンモニア性窒素の増大, 溶存酸 素不足といら事態に至っては, アンモニアを硝化しき れないのみでなく, マンガンイオンの漏出が起こった。

一方急速濾過方式では，アンモニアの硝化はできな いので, 残留塩素は結合形となっていた。この両方式 が季節によってそれぞれ処理効率が異なり，給水する ときの残留塩素は遊離形となったり，結合形になった りしたので, 両系統の水が混合する市内区域では残留 塩素が零になることもあった。また結合形の残留塩素 では, 異臭 (土臭, 下水臭) を感ずるなどの苦情が出 たりしだ)。

このため, 緩速濾過については, 曝気設備を設ける 等の実験をした結果と, 将来にわたって安定的に濾過 砂を入手できる目途もないことも考慮して廃止するこ ととし, 急速濾過については, 不連続点前塩素処理を
採用したのである4),5)

\section{2 淀川における水質異変例}

中性洗剂の泡立ち, PCBによる污染等, これまでと ちがった新しい污染物質の測定や水源監視が必要に なってきた。淀川では大事に至る事故はなかったが, 有機的污濁による降雨時の黒濁り現象以外にも水質異 変が起こるようになってきた。

(1) フェノール污染事故

昭和 32 年 3 月市民から異臭味の申告があり，調査の 結果, 原水中に混入したフェノールが塩素と反応して 生成したクロロフェノールによるものと考学れれた。 淀川原水にフェノールが $24 \sim 42 \mu \mathrm{g} / \ell$ あ，その排出 源は工場排水によるものと考光て，上流の工場排水の 水質調査を実施し，いくつかの工場がフェノール活染 源と判明したので，関係機関を通じて指導を打願いし た1)。

水道事業者にとっては，全く法的権限の拈よばない ところではあるが，大阪市水道局では水道水源を守る 立場から，現在でも淀川へ直接放流する 8 工場につい て工場側の協力を得て，定期的に排水の水質試験を実 施している。

（2）シクロヘキシルアミン系物質による異臭

昭和 43 年 3 月から 44 年11月にかけて，9 回にわたり 強い刺激臭が浄水に感じられた。この異臭が塩素との 反応で生ずることは確認できたが，原因者を特定でき なかった。約 1 年後に原因工場をつきとめることがで き，関係機関から指導を打願いした6)。

(3) 産業廃棄物投棄地からの廃油流出事故

昭和 46 年 5 月, 降雨により枚方市内の産業廃棄物投 棄地から廃油が流出し, 農業用水路, 小河川を経て淀 川に流出した。枚方市と関係水道事業体は協力して築 堤工事をする等流出をくい止めた7)。降雨時, 原因者不 明の油の流下は，この時期しばしばみられたのである。

(4) その他

シアン流出事故, 農薬流出等の事故もあったが, 関 係者の協力により大事には至っていない。しかし，不 法投棄も含めてこうした水質異変の危険性はあり, 各 浄水場では魚の飼育槽を用意して毒物の検知を図って いる。大阪市では，魚が死に至る前の段階，毒物の低 濃度領域で, 魚の生理的変化を電気信号としてとらえ る魚による原水監視装置を考案した ${ }^{8)}$ 。実用化には至っ ていないが，周辺装置の技術的開発状況をみながら実 用化を目指したい。

年度別水質異変発生状況は表 1 に示すとおりで, 最 近減少してきている。これは法的規制，あるいは排水 処理施設が整備されてきたことによるものであるが, 水道事業者の水源監視活動, PR の効果も大きいもの 
と考えている。

\section{2. 水源水質監視体制}

前項で述べたように淀川の急激な污濁に対処して水 道事業体は，水源を守るといら自衛の立場から，権限 のないまま各種の調査を実施していた。

国においては，昭和 26 年経済安定本部資源調査会の 「水質污濁に関する勧告」を受けて以来, その法制化に 向けて関係省庁の連絡協議会が設けられ, 淀川につい ても実態調査が行われることとなった。淀川について は, 昭和 29 年「水質污濁防止関西地区協議会」が設置 されて, 実態調査が進められた。以後順次, 水質污濁 防止に関する法体系が整備されてきた9)。

現在, 淀川水系では, 水道事業体も参画して活発に 活動している 2 つ協議会がある。

\section{1 淀川水質污濁防止連絡協議会}

「水質污濁防止関西地区協議会」が実態調査を終え, その任務を終了したが, その組織を活用して昭和 33 年, 近畿地方建設局, 大阪通産局をはじめ, 関係府県市を もって「淀川水質污濁防止連絡協議会」を結成したも のである。水質保全, 下水道総合計画, 水質監視委員 会が設置されて扣り，淀川水系の水質調査とその整理 記録を行い，琵琶湖から大阪湾に至る広範囲な水質の 年々の水質污濁状況を把握している。また，水質異変 時の連絡組織網が設けられて括り，異変時の情報交換 と適切な措置がとられるようにしている。

水道に直接関係する琵琶湖のカビ臭発生と対策につ いては異臭小委員会が設置され, 関係者協同で調査研 究しているところである。

\section{2 淀川水質協議会}

前記協議会とは別に, 水道事業者が独自に緊密な連

表 1 年度別原水水質異変発生件数

\begin{tabular}{|c|c|c|c|c|c|c|c|c|c|c|c|}
\hline 年度 & 油 & 色 & 異臭 & $\begin{array}{l}\mathrm{p} \mathrm{H} \text { 值 } \\
\text { 上 昇 }\end{array}$ & $\begin{array}{l}\text { 濁度 } \\
\text { 上昇 }\end{array}$ & 農薬 & 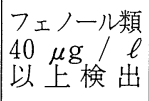 & シアン & 魚浮上 & その他 & 計 \\
\hline 38 & 1 & & & & & & 1 & & & & 2 \\
\hline 39 & 1 & & & & & & & & & & 1 \\
\hline 40 & 3 & & & & & & 1 & & & & 4 \\
\hline 41 & & 7 & & & & & & 1 & & & 8 \\
\hline 42 & 2 & 1 & 2 & & & & & 1 & & 2 & 8 \\
\hline 43 & 13 & 3 & 2 & & 1 & 1 & & & & 1 & 21 \\
\hline 44 & 4 & 10 & 7 & & & & & & 4 & 11 & 36 \\
\hline 45 & 10 & 2 & 3 & & 2 & & & & 6 & 8 & 31 \\
\hline 46 & 23 & 3 & 3 & & & & & 2 & 4 & 2 & 37 \\
\hline 47 & 9 & 2 & 2 & & 1 & & 2 & 1 & 6 & 1 & 24 \\
\hline 48 & 16 & 4 & & & 2 & & 1 & 3 & 5 & 6 & 37 \\
\hline 49 & 18 & 1 & & & & & 1 & & 2 & 3 & 25 \\
\hline 50 & 14 & & 1 & & 1 & 1 & & & 5 & 3 & 25 \\
\hline 51 & 10 & & & & & & & & 3 & 2 & 15 \\
\hline 52 & 6 & 1 & & & & & & & 4 & 2 & 13 \\
\hline 53 & 8 & & 1 & & 1 & & & & 2 & 2 & 14 \\
\hline 54 & 1 & & & & & & 1 & & 1 & & 3 \\
\hline 55 & 2 & & 3 & & & & & & 1 & 1 & 7 \\
\hline 56 & 1 & 1 & 1 & & & & & & & 1 & 4 \\
\hline 57 & 2 & & 3 & & 1 & & & & 7 & & 7 \\
\hline 58 & 4 & & 2 & & & & & & 2 & & 8 \\
\hline 59 & 4 & 1 & 2 & & & & 2 & & 3 & 2 & 14 \\
\hline 計 & 153 & 36 & 34 & 1 & 10 & 3 & 10 & 8 & 49 & 49 & 353 \\
\hline
\end{tabular}


絡をはかりながら水質污濁の監視にあたるとともに， 淀川から取水する水道の共通の問題を調查研究する場 として，昭和 40 年「淀川水質協議会」が結成された。

現在 8 事業体で構成している。この協議会の目的は (1)淀川から取水する水道事業者相互間に掞いて, 淀川 の水質について連絡をはかること，(2)淀川の水質改善 について関係先へ要望し意見を述べること, (3)淀川の 水質について調查研究を行い関係先一周知徹底をはか ること, (4)淀川への排水施設の改善等について, 助言 または要望をすること, (5)淀川の水質污濁防止ならび に水質保全に関する PR を行うこと，等である。

また, カビ臭, トリハロメタン, 変異原性物質等に ついてはそれぞれ小委員会を設け, 調査するような活 動も行っている。

\section{3. 大阪市における水道水の安全性向上に関する調査 研究}

淀川の現在の水質は, 水質污濁に関する法体系の整 備, 下水道整備の進歩により BOD のような水中の酸 素消費に関する指標でみると改善されてきて拈り，小 康状態を保っているとい方る。

現在の淀川水質の問題点は, アンモニアと塩素消毒 の問題, 窒素, リン等による琵琶湖の富栄養化とカビ 臭の問題があり，一方で新たな化学物質による污濁の 問題がある。

高度経済成長期には，重金属が人の健康との関係で 注目された。大阪市では, 昭和 43 年, 原子吸光光度計 を導入し，短時間に簡便に ppbレベルまで測定できる よらになった。このような重金属をはじめ無機物質に よる水質污濁の原因は, 工場排水による場合が多いか ら法的規制と監視で比較的容易に解決される。

しかし，有機物については，種類も多く分析方法も 確立されていないものが多い。有機物の個々の分析技 術の開発を進める一方で, 有機物の総括的水質指標の 開発も必要である。従来水道水源としての一般的な有 機物の水質指標として, BOD を利用してきた。しかし， 淀川に排出される排水のうち, 生物処理された排水の 割合が高くなってきて打り，5 日間 BOD 值を測定す る際, アンモニアの硝化による酸素消費が入ってきて おり，BOD の中味が問題となってきている10)。

大阪市では, 有機物指標としてけい光強度, 紫外部 吸光度, TOC 等の持つ意味と測定上の限界を認識した らえで, 総合的判断にどう役立てられるか種々データ の集積をはかっているところである。

\section{1 微量有機物に関する調査}

(1) 分析方法の開発

大阪市では昭和 45 年にガスクロマトグラフを導入
し，有機物の測定にとりかかった。しかし，分析方法 が充分確立されていなかったので，PCB，フタル酸エ ステル, アクリルアミドモノマー程度の分析しかでき なかった。昭和 52 年にガスクロマトグフ質量分析計 （GC-MS）を導入してから次第に手がかりを得るこ とができるようになり，今日までに，トリハロメタン とカビ臭物質の簡便で精度の良い測定法を開発してき $た^{11,12) 。}$

水道水中には, 何百種類もの微量有機物質が含まれ ているといわれている。これらの物質は水道で制御す るのは不可能であるとはい充, それらの分析之評価へ の努力を怠っては水道事業者としての当事者能力を失 らことになる。少なくとも $\mathrm{WHO}^{13)}$ ，米国 $\mathrm{EPA}^{14)}$ で議 論されているよらな有機物については，分析できる能 力をつけておく必要があると考学る。

大阪市では技術能力と経済性を考慮しつつ, 分析機 器の整備につとめているところである。最近導入した ものに, 高速液体クロマトグラフ, イオンクロマトグ ラフ, キャピラリーガスクロマトグラフ等があり,

$\mathrm{GC}-\mathrm{MS}$ \& 3 台に増強した。

WHO は, 1984年に新たに18の有機物についてガイ ドライン值を設定した。しかし，分析方法については 示されて扣らず，ガイドライン值の $1 / 10$ の濃度が測 定できることを指定しているだけである13)。大阪市で は GC一MSを用いて, 今をで測定したことのない物 質を中心に WHO がガイドライン值を設定した物質 の測定法を検討し, 同時に淀川の実態を調査した ${ }^{15)}$ 。結 果は表 2 に示すと扣りであり, 測定方法はガイドライ ン值の $1 / 10$ を測定できること,またこれらの物質は, 淀川にはガイドライン值と比較して問題とする量は含 まれていないことが判明した。

(2) 淀川における農薬污染

農薬は種類も多く, 分析方法もわからないものが多 い。これまで問題になりそらなものについては，その つど，分析方法の調查と測定を行ってきている。有機 塩素系農薬に関しては, 昭和54年以来継続して調査し て扣り, 淀川枚方地点の結果は表 3 に示すと佂りで, 問題とする量を検出していない15)。

(3) 浄水処理技術に関する調査

水道水中に何百もあるといわれている化学物質につ いて，1つ1つを同定してその処理性を論ずることは 不可能である。それらを一括して, 全体として安全性 を向上させる処理技術が必要と考兄る。現在実施可能 な技術として，オゾン処理，活性炭処理，生物処理技 術があげられる。大阪市では, カビ臭物質をはじめと する微量有機物低減化対策として, オゾン処理, 活性 炭処理, 生物処理のパイロットプラントによる実験を 
表 2 淀川柴島净水場原水及び浄水中微量有機物質

$(\mu \mathrm{g} / \ell)$

\begin{tabular}{|c|c|c|c|c|c|}
\hline \multirow{2}{*}{ 化 合 物 名 } & \multirow{2}{*}{ 濃縮法 } & \multirow{2}{*}{ 検出下限 } & \multicolumn{2}{|c|}{ 測定結果 } & \multirow{2}{*}{$\begin{array}{c}\text { WHO } \\
\text { ガイドライン值 }\end{array}$} \\
\hline & & & 原 水 & 浄 水 & \\
\hline ベンゼン & ヘッドスペース法 & 1 & 0 & 0 & 10 \\
\hline 1.1-ジクロロエチレン & ヘッドスペース法 & 0.5 & 0.0 & 0.0 & 0.3 \\
\hline クロロベンゼン & パージ・トラップ法 & 0.005 & 0.00 & 0.00 & \\
\hline O-ジクロロベンゼン & パージ・トラップ法 & 0.01 & 0.08 & 0.07 & \\
\hline p-ジクロロベンゼン & パージ・トラップ法 & 0.01 & 0.12 & 0.10 & \\
\hline m-ジクロロベンゼン & パージ・トラップ法 & 0.01 & 0.01 & 0.01 & \\
\hline 1.2.3-トリクロロベンゼン & パージ・トラップ法 & 0.01 & 0.10 & 0.04 & \\
\hline 1.2.4-トリクロロベンゼン & パージ・トラップ法 & 0.01 & 0.20 & 0.06 & \\
\hline 1.3.5-トリクロロベンゼン & パージ・トラップ法 & 0.01 & 0.00 & 0.00 & \\
\hline ヘキサクロロベンゼン & 溶媒抽出法 & 0.01 & 0.00 & 0.00 & 0.01 \\
\hline メトキシクロル & 溶媒抽出法 & 0.01 & 0.00 & 0.00 & 30 \\
\hline ヘプタクロール & 溶媒抽出法 & 0.05 & 0.00 & 0.00 & 0.1 \\
\hline ヘプタクロルエポキシド & 溶媒抽出法 & 0.3 & 0.0 & 0.0 & 0.1 \\
\hline O-クロロフェノール & 溶媒抽出法 & 0.01 & 0.0 & 0.0 & \\
\hline m-クロロフェノール & 溶媒抽出法 & 0.02 & 0.0 & 0.0 & \\
\hline 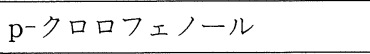 & 溶媒抽出法 & 0.02 & 0.0 & 0.0 & \\
\hline 2.6-ジクロロフェノール & 溶媒抽出法 & 0.02 & 0.0 & 0.0 & \\
\hline 2.4-ジクロロフェノール & 溶媒抽出法 & 0.02 & 0.0 & 0.0 & \\
\hline 2.4.6-トリクロロフェノール & 溶媒抽出法 & 0.02 & 0.0 & 0.0 & 10 \\
\hline ペンタクロロフェノール & 溶媒抽出法 & 0.02 & 0.0 & 0.0 & 10 \\
\hline ベソゾ $(\mathrm{a})$ ピレン & 溶媒抽出法 & 0.05 & 0.00 & 0.00 & 0.01 \\
\hline
\end{tabular}

表 3 淀川枚方大橋（環境基準点）における有機塩素系農 薬

\begin{tabular}{|c|c|c|c|c|c|c|c|}
\hline 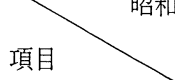 & 54 & 55 & 56 & 57 & 58 & 59 & 60 \\
\hline$\alpha-\mathrm{BHC}$ & 0.000 & 0.028 & 0.025 & 0.020 & 0.016 & 0.015 & 0.000 \\
\hline$\beta-\mathrm{BHC}$ & 0.08 & 0.04 & 0.03 & 0.06 & 0.02 & 0.03 & 0.00 \\
\hline $\mathrm{r}-\mathrm{BHC}$ & 0.000 & 0.001 & 0.002 & 0.002 & 0.005 & 0.005 & 0.000 \\
\hline$\delta-\mathrm{BHC}$ & 0.000 & 0.000 & 0.001 & 0.003 & 0.000 & 0.001 & 0.000 \\
\hline アルドリン & 0.000 & 0.002 & 0.000 & 0.000 & 0.000 & 0.003 & 0.000 \\
\hline PP'-DDE & 0.000 & 0.000 & 0.000 & 0.000 & 0.000 & 0.004 & 0.000 \\
\hline ディルドリン & 0.000 & 0.000 & 0.000 & 0.000 & 0.000 & 0.000 & 0.000 \\
\hline DDD & 0.000 & 0.000 & 0.000 & 0.000 & 0.000 & 0.000 & 0.000 \\
\hline PP'-DDT & 0.00 & 0.00 & 0.00 & 0.00 & 0.00 & 0.00 & 0.00 \\
\hline エンドリン & 0.00 & 0.00 & 0.00 & 0.00 & 0.00 & 0.00 & 0.00 \\
\hline
\end{tabular}

継続してきた。この実験での処理性評価に，これまで に開発した分析技術が大いに役立っていることはいら までもない。

例光ば，活性炭濾過によるトリハロメタン前駆物質 の低減量は図 3 に示すよらになる。したがって, 活性 炭濾過を実施したと想定すると，この処理水に塩素を 注入することになるから水道水のトリハロメタンは現 在の $1 / 2$ またはそれ以下となり,これは污染を全く受 けていない自然水を直接原水として利用するのと同程 度と推定される。

現在, 維持管理上の問題等, 設計諸元を得るために, 実証プラント $\left(2,000 \mathrm{~m}^{3} /\right.$ 日)による実験を行っている ところである。

\section{2 水源水質污濁に関する調柤}

(1) 琵琶湖富栄養化に関する調査

琵琶湖で発生するカビ臭について, 発生原因, 予測, 対策について, 淀川水質污濁防止連絡協議会, 淀川水 


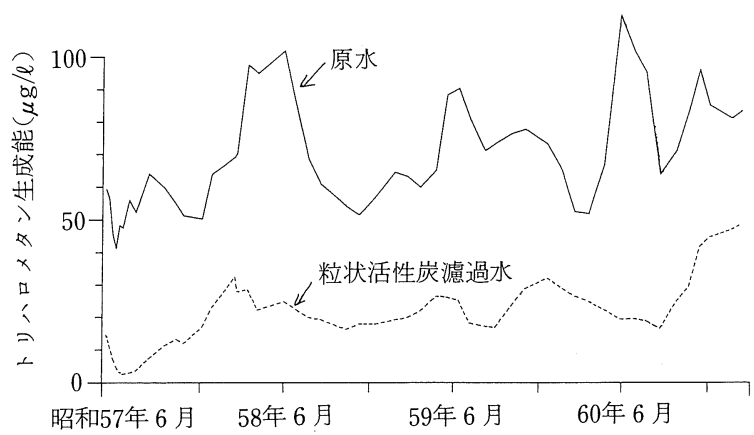

図 3 淀川柴島浄水場原水のトリハロメタン生成能の経年 変化と粒状活性炭濾過による低減効果

質協議会と協同で調査している。

（2）淀川水系に扣ける人為的派濁源の負荷量調査 淀川水質污濁防止連絡協議会, 淀川水質協議会で協 同で調査している。

\section{3 給水栓水の監視}

水道にとってもっとも重要なことは, 給水栓水の安 全の確認である。直接採水による日常試験と合わせて, 連続自動監視装置（8台）を設置している。

\section{おわりに}

最近に扣ける淀川の水質污濁の状況と大阪市に拈け る調査研究の概要を紹介してきた。水道水の安全性を 確保するには, 水源水質の保全, 浄水処理過程に扣け る安全性の向上と, 給配水施設内での水質劣化を招か ないことが重要である。浄水場でいかに完全に処理し ようとも, 給配水施設内で水質劣化があっては, 安全 は確保されない。大阪市では，浄水処理技術の開発と 併行して，給配水施設内の水質変化に関する調査を実 施している。現在, 給水中の微量な有機物の量と質が, 塩素消費に大きく関与していることを見出したところ である ${ }^{16)}$ 。今後も市内給水栓水の連続自動監視装置を 活用して水質変化を追跡する予定である。

まだ着手していない調査研究課題には，変異原性に 関するものとウイルスに関するものがあり，これらに 関する知見を収集している段階である。また，浄水処 理技術が塩素を使用しない方式になれば，浄水処理過 程に括ける微生物の挙動が重要となってくる。大阪市 にはプランクトンの挙動については多くの知見が蓄積
されているが，バクテリアについての知見は少ない。 今年度から浄水処理過程に怙けるバクテリアの挙動に ついての調査に着手したところである。

このように, より安全な水を目指して調査すべき課 題が多く残されている。今後の分析技術の進歩は，よ り多くの情報を我々にもたらしてくれるであろら。し かし水道の分析技術は単に物質を測定するのみに終 わってはならず，水処理に打ける処理性の評価と安全 性の確認と監視に役立てられなければならない。

水道に扣ける安全性向上に関する調査研究の成果 が，水道にとってもっとも重要な水源水質保全施策に 生かされるよう，不断の努力が必要である。

\section{文献}

1 ) 水川健次 (1968）淀川に抢ける原水水質異変, 水道事業研究 60 号, 大阪市水道局.

2 ）八木正一 (1984) 河川と水質, 土木学会誌, 9 月号.

3 ) 柴島浄水場浄水係（1963）淀川水系の異常渴水々浄水作業記 録, 水道事業研究 49 号, 大阪市水道局.

4 ) 吉竹俊治 (1967) 柴島浄水場浄水設備改良について, 水道事 業研究59号, 大阪市水道局.

5 ）淀川水質協議会（1970）淀川水系の渴水期に扣ける原水水質 と浄水処理, 水道協会雑誌第 435 号.

$6 ）$ 淀川水質協議会（1975）淀川水質協議会拾年の歩み.

7 ）玉井義弘, 水川健次（1971）産業廃棄物投棄所からの廃油流 出による淀川原水異臭事故経過報告水道事業研究71号.

8 ）松尾雄三（1985）フナのえら蓋の活動電位による急性毒性の 監視実験, 水道協会雑誌, 54, 10 .

9 ）大阪市水道局（1982）大阪市水道80年史.

10）大阪市水道局（1981）水質保全問題の基本的調査（その 2 ） 報告書.

11）梶野勝司（1977）塩素処理に括けるトリハロメタンの形成, 水道協会雑誌, No.514.

12）梶野勝司, 藤本信之, 芦谷和芳, 八木正一（1984）パージト ラップーマスフラグメントグラフィによる水中及び藍藻培養液 中の 2 -メチルイソボルネオールとジオスミンの超微量分析, 水道協会雑誌, 600 .

13) World Health Organization (1984) Guidelines For Drinking-Water Qual 慎慢訪(1) 1, Recommendations

14) U.S. EPA (1985) “Federal Register” Part III, 46880-46933

15）藤本信之, 芦谷和芳 (1986)WHO ガイドラインに示された有 機物の GC-MS による測定, 大阪市水道局水質試験所調査研 究ならびに試験成績第 36 集

16）松井克肇, 徳光信治, 奥勇治（1986）市内給水栓水の残留塩 素適正保持に関する一考察, 第37回全国水道研究発表会概要集 